乗峯絵理 ${ }^{1,3}$, 宮田勝文 ${ }^{1}$, 石澤不二雄 ${ }^{1}$, 鷹巣正則 ${ }^{2}$, 本田克也 ${ }^{3}$

\author{
1茨城県警察本部刑事部科学捜査研究所 \\ 干310-8550 茨城県水戸市笠原町978-6 \\ 2 茨城県警察本部刑事部捜査一課 \\ 干310-8550 茨城県水戸市笠原町978-6 \\ 3 筑波大学人間総合科学研究科生命システム医学専攻法医学 \\ 干305-8577 茨城県つくば市天王台 1-1-1
}

\title{
Analysis of Helium in Blood
}

\author{
Eri Norimine ${ }^{1,3}$, Katsufumi Miyata ${ }^{1}$, Fujio Ishizawa ${ }^{1}$, \\ Masanori Takasu ${ }^{2}$ and Katsuya Honda ${ }^{3}$ \\ ${ }^{1}$ Forensic Science Laboratory, Ibaraki Prefectural Police H.Q. \\ 978-6 Kasahara-cho, Mito-shi, Ibaraki, 310-8550, Japan \\ ${ }^{2}$ First Criminal Investigation Division, Ibaraki Prefectural Police H.Q. \\ 978-6 Kasahara-cho, Mito-shi, Ibaraki, 310-8550, Japan \\ ${ }^{3}$ Field of Legal Medicine, Doctoral Program in Life System Medical Sciences, \\ Graduate School of Comprehensive Human Sciences, University of Tsukuba \\ 1-1-1 Tennodai, Tsukuba-shi, Ibaraki, 305-8577, Japan
}

\section{(Received 10 January 2012; accepted 9 July 2012)}

The authors have reported 4 successfully-detected cases of helium in postmortem blood by headspace-gas chromatography (HS-GC). Postmortem blood was collected into a depressurized 4-ml glass vial to prevent volatilization loss of helium. MICROPACKED-ST column $(2.0 \mathrm{~m} \times 1.0 \mathrm{~mm}$ i.d., $80 / 100 \mathrm{mesh})$ was used as a separation column, and thermal conductivity detector was selected as a gas chromatographic detector. Argon was used as a carrier gas, and the flow rate was set at $8.3 \mathrm{ml} / \mathrm{min}$. After $0.5 \mathrm{ml}$ air was released into the vial, $0.5 \mathrm{ml}$ headspace gas was manually injected to the instrument. In this analytical condition, helium was wellseparated from other gases in the atmosphere. This HS-GC method was applied to real blood samples of 4 suspected cases of helium inhalation, resulting in successful detection of helium in blood in all cases.

In the case of a suicide by helium inhalation, it is generally difficult to determine the cause of death from an autopsy finding. This case report provides a practical method to obtain direct proof of helium inhalation.

Key words: Helium, Suicide, Headspace-GC, Blood 


\section{緒 言}

希ガスの 1 つであるへリウムは, 無色, 無味, 無 臭, 不燃性の気体で, 大気中の含有率は 0.0005 $\operatorname{vol} \%{ }^{1)}$, 血液への溶解度は $0.008 \mathrm{ml} / \mathrm{ml}$ とされてお り2)，他のガスと比較して血液に溶けにくいガスで ある（Table 1)。ヘリウムは化学的に安定であるた め，生体に対する薬理的作用をほとんど有しないと されている2．，一般に風船などの浮揚用ガスとして 用いられ，玩具店やインターネット上で安価な值段 で購入可能である.

茨城県におけるこれまでの手段別ガス自殺の件数 推移を見ると，以前は排ガス自殺が中心であった が，近年は練炭自殺が主流となっており，さらに 2008年から硫化水素自殺が数多く発生するようにな った。また，2010年からへリウムを使用した自殺が 散見されるようになった トでは，アメリカの安楽死協会が推奨する方法とし てヘリウムを用いた自殺方法が紹介されおり，手順 を紹介した動画や，詳細な手順が記載されたサイト もある．海外では，へリウムを使用した自殺の報告 は多数あるが，多くの場合，状況証拠からへリウム を吸引して自殺を図ったものと判断されて抒 り4-6)，生体試料からへリウムを検出した報告は非 常に少ない。また，生体試料からへリウムを検出し た報告を見ると，いずれも解剖試料（肺，脳，気道 ガスなど）を分析しており 7-9)，その中で血液から 検出した報告はこれまでに 1 例のみである10).

ヘリウムを用いた自殺事案は今後増加が予想され るため，ヘリウム吸引の証明として血液からへリウ ムを検出することは重要である，そこで血中へリウ ムの分析方法について検討を重ねたところ，検視で 採取した血液からへリウムの検出が可能であったの で報告する。

\section{材料および方法}

\section{1. 材料}

水はミリポア社製 MilliQ SP ICP-MS システム により製造した超純水を用いた。ヘリウム（純度 $99.9995 \%$ 以上), 水素（純度 $99.99999 \%$ 以上), 窒 素（純度99.9995\%以上), メタン（濃度 $10.1 \%$, ア
Table 1 Solubilities of various gases in blood.

\begin{tabular}{cc}
\hline Gas & $\begin{array}{c}\text { Solubility in blood } \\
\left(\mathrm{ml} \text { gas } / \mathrm{ml} \text { blood, } 37^{\circ} \mathrm{C}\right)\end{array}$ \\
\hline Helium & 0.008 \\
Nitrogen & 0.013 \\
Oxygen & 0.024 \\
Carbon dioxide & 0.60 \\
\hline
\end{tabular}

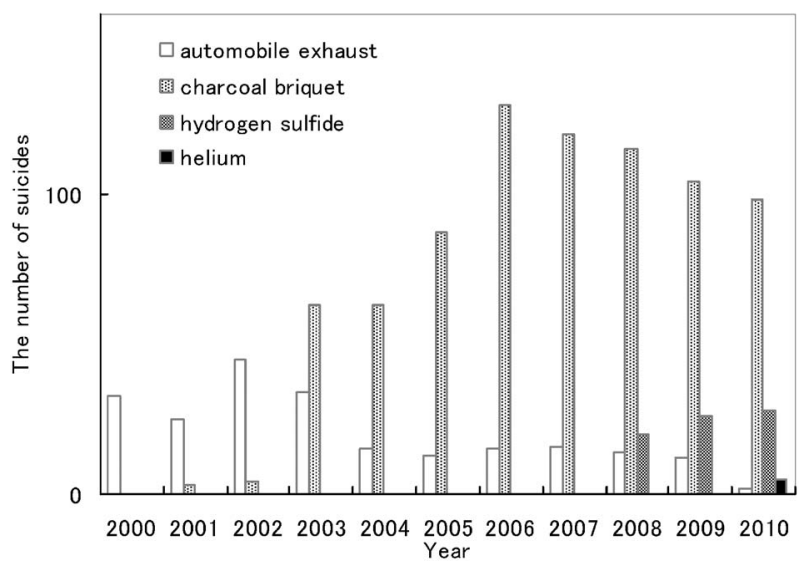

Fig. 1 Number of suicides by gas inhalation in Ibaraki Prefecture.

ルゴンとの混合ガス）は太陽日酸社より入手した． 純酸素 $(99.9 \%)$, 純二酸化炭素 $(99.9 \%)$ ，プロパ ン（99.5\%）は，ジーエルサイエンス社，一酸化炭 素（99.9\%）はガスクロ工業社の標準ガスを使用し た。フロンとして ENGINEERInc.のエアロダス ター $(\mathrm{HFC} 134 \mathrm{a})$ ，ライター用ガスとしてヨシナガ 社製プリンスガスバーナー専用ガスボンベを使用し た。乾燥空気は日立製作所製小型空気圧縮機で製造 した空気を使用した。他の空気は実験室空気を使用 した。プラスチックディスポシリンジ（容量 $6 \mathrm{ml}$ または $60 \mathrm{ml}$ ）は市販のポリプロピレン製のものを 用いた。ガスタイトシリンジは SGE 製，シリンジ に装着する針はジーエルサイエンス製ロック型普通 針を用いた。オートサンプラー用バイアルは島津製 作所製の $4 \mathrm{ml}$ バイアルを用いた。容量 $2 \mathrm{~L}$ のテド ラーバッグは市販のフッ化ビニル樹脂製のもの，ア ルミニウムバッグはジーエルサイエンス社のものを 使用した。ヘッドスペース用バイアルは島津 GLC 社製のものを使用した。 


\section{2. 試料の調製および分析}

\section{2-1 各種ガス試料の分析}

各種ガス試料は，いずれもへッドスペース用バイ アルに入れ，分析時にバイアルから $0.5 \mathrm{ml}$ を採取し てガスクロマトグラフ (GC) へ注入した.

\section{2-2 実試料の分析}

実試料は，検視で採取した血液（4 例）である。 検視の際，注射器により採取した血液は，直ちにあ らかじめ減圧しておいた $4 \mathrm{ml}$ のオートサンプラー 用バイアルに入れ試料とした。試料の液量は約 2 $\mathrm{ml} \sim 4 \mathrm{ml}$ であった。試料は冷蔵保管し, 採取から 数時間〜 4 日後に分析に供した. GCへのへッドス ペースガス注入量は, $0.5 \mathrm{ml}$ とした.

事例 1, 2, 4 では血液を加熱してからへッドス ペースガスを GCへ注入した．また，事例 $2 \sim 4$ で は，バイアルがあらかじめ減圧になっていたことを 考慮し, 実験室空気（ヘリウムが検出されないこと を確認したもの） $0.5 \mathrm{ml}$ をバイアルに注入してから ヘッドスペースガスを採取，分析した。

\section{2-3 前処理条件の検討}

加温の効果， $\mathrm{GC} へ の$ 注入量および注入法につい て検討を行うため，ヘリウム水溶液を調製した．水 で満たしたアルミニウムバッグにヘリウム $160 \mathrm{ml}$ を入れ，ヘリウム飽和状態となるようにした．オー トサンプラー用バイアルを密栓した後，プラスチッ クシリンジで $20 \mathrm{ml}$ の目盛りまでピストンを引いて 減圧状態とし，そこへアルミニウムバッグから採取 したへリウム水溶液を $2 \mathrm{ml}$ 注入した.

加温の効果を調べるため，ヘリウム水溶液を入れ たバイアルを，室温または $60^{\circ} \mathrm{C}$ 温浴内で 15,30 お よび60分静置した後，ヘッドスペースガス $0.5 \mathrm{ml}$ を $\mathrm{GC}$ へ注入し $(n=3)$ ，ピーク面積を比較した。

また， $\mathrm{GC} へ の$ 注入量を $0.5 \mathrm{ml}$ および $1.0 \mathrm{ml}$ とし たときのピーク面積を比較した $(n=3)$. さらに，

スプリット注入法（スプリット比 $1: 10,1: 5$ ), ス プリットレス注入法，スプリットレス高圧注入法に ついて検討した $(n=3)$.

\section{3. 分析条件}

装置：島津製作所製 GC-17A

カラム：信和化工株式会社製 MICROPACKED -ST $(2.0 \mathrm{~m} \times 1.0 \mathrm{~mm}$ i.d. $80 / 100 \mathrm{mesh})$
キャリアガス : アルゴン（流量 : $8.3 \mathrm{ml} / \mathrm{min}$ )

入口圧 : $180 \mathrm{kPa}$

カラムオーブン温度: $35^{\circ} \mathrm{C}(2$ 分 $) \sim 5^{\circ} \mathrm{C} / \mathrm{min} \sim 80$ ${ }^{\circ} \mathrm{C}(4$ 分 $) \sim 10^{\circ} \mathrm{C} / \mathrm{min} \sim 100^{\circ} \mathrm{C}(3$ 分 $)$

スプリット比 $: 1: 10$

注入口温度 $: 100^{\circ} \mathrm{C}$

検出器 : TCD（極性マイナス）

検出器電流 : $40 \mathrm{~mA}$

検出器温度 : $100^{\circ} \mathrm{C}$

\section{結果および考察}

\section{1. 各種ガスの検出}

前記の分析条件で各種ガスを分析した結果を Fig 2 に示す。保持時間約 0.5 分にヘリウムのピークが 検出され，以降水素，酸素，窒素，一酸化炭素，メ タン，二酸化炭素の順で検出された。これら以外の ガスとして，自殺などで用いられるプロパン， HFC134a，ライター用ガス（ブタン，イソブタン） は, 今回の分析条件では検出されなかった。

\section{2. 事例}

血中ヘリウム検出事例を 4 例紹介寸る. 今回紹介 する事例以前に発生した，ヘリウムを用いたと推定 された自殺事案では, 検視の際にプラスチックチ ューブに血液を入れ，それをバイアルに移し替え， そのヘッドスペースガスの分析を行っていた。しか しながら，この方法では試みた 6 例全てでヘリウム を検出できなかった．この原因として，ヘリウムが 元々血液に溶け込みにくく, プラスチックチューブ 内で既に気相に抜けており，蓋を開けた時点で空気 中に拡散してしまったため，また，バイアルに移し 替える作業を行う間に空気中に拡散してしまったた

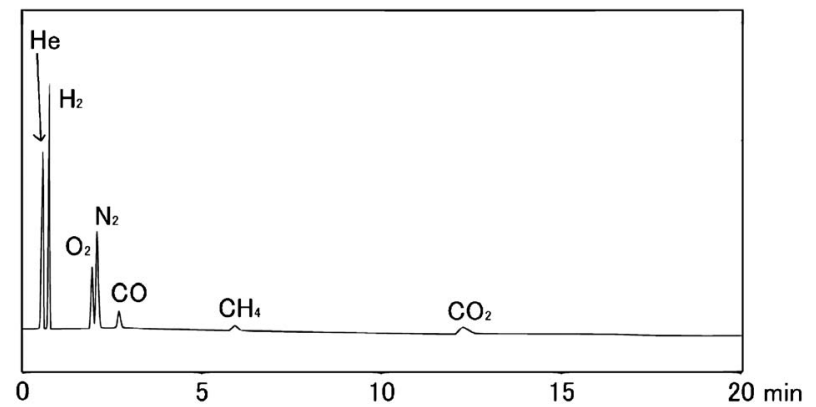

Fig. 2 Gas chromatogram of standard gases. 
めと考えられた. そこで，オートサンプラー用のバ イアルをあらかじめ密栓した後, 中の空気をシリン ジで抜き，セプタムを介して採取した血液を入れる 方法に変更したところ，この方法で血液を採取した 4 例でヘリウムの検出に成功した.

〈事例 1〉自宅でポリ袋をかぶりへリウムを引いて 自殺を図っていたもので，死者には溢血点などの法 医学的所見は認められなかった。試料の血液は約 2 $\mathrm{ml}$ であった。死者の死亡推定日から採血までの日 数は 1 日，採血から分析までの日数は 4 日であっ た。試料の入ったバイアルを $60^{\circ} \mathrm{C} て ゙ 10$ 分間加熱し， ヘッドスペースガスを分析した結果を Fig. 3 case 1 に示す．保持時間約 0.5 分にへリウムが検出され た。死亡から採血までの日数が 3〜 5 日程度であれ ばへリウムの検出可能であるとの報告もあり ${ }^{8)}$, 本 事例では死亡から採血までの時間は 1 日であったこ 々, また, 密閉容器に保存していたことから, 分析 までの日数が 4 日と長かったにも関わらず，ヘリウ ムの検出が可能であったと考えられる.

〈事例 2〉自動車内にへリウムボンベを持ち込んで 自殺を図っていたもので, 死者の片目の眼瞼には溢
血点が 1 つだけ認められた。試料の血液は約 $2 \mathrm{ml}$ であった. 死亡推定日から採血までの日数は 2 日， 採血から分析までの日数は 1 日であった。試料を 40 ${ }^{\circ} \mathrm{C}$ で30分間加熱し，元々バイアルが減圧されていた ことを考慮してヘッドスペースガス採取前にバイア ル内に空気 $0.5 \mathrm{ml}$ を入れ，ヘッドスペースガス 0.5 $\mathrm{ml}$ を採取し，GCへ注入した（Fig. 3 case 2)。保 持時間約 0.5 分にヘリウム, 約 0.7 分に水素が検出さ れた。なお，水素は，一般に難消化性の炭水化物 （オリゴ糖や食物繊維）を摂取した際に腸内細菌の 発酵によって生成するとされている11).

〈事例 3〉自動車内にヘリウムボンベ 2 個を持ち込 んで自殺を図ったもので，死者の眼瞼は充血してい た．死者が頭にかぶったポリ袋の口には密閉するた めにへアバンドが付けられていたが，輪ゴムなどと 異なり幅が太いため, 首に索溝なども観察されなか った．試料の血液は約 $3 \mathrm{ml}$ であった．本事例では 死亡推定日から分析まで 1 日以内で行われた。 バイ アルが減圧であることを考慮して分析前にバイアル に空気 $0.5 \mathrm{ml}$ を入れ，ヘッドスペースガス $0.5 \mathrm{ml}$ $\mathrm{GC}$ へ注入した. 分析の結果（Fig. 3 case 3 ），事例
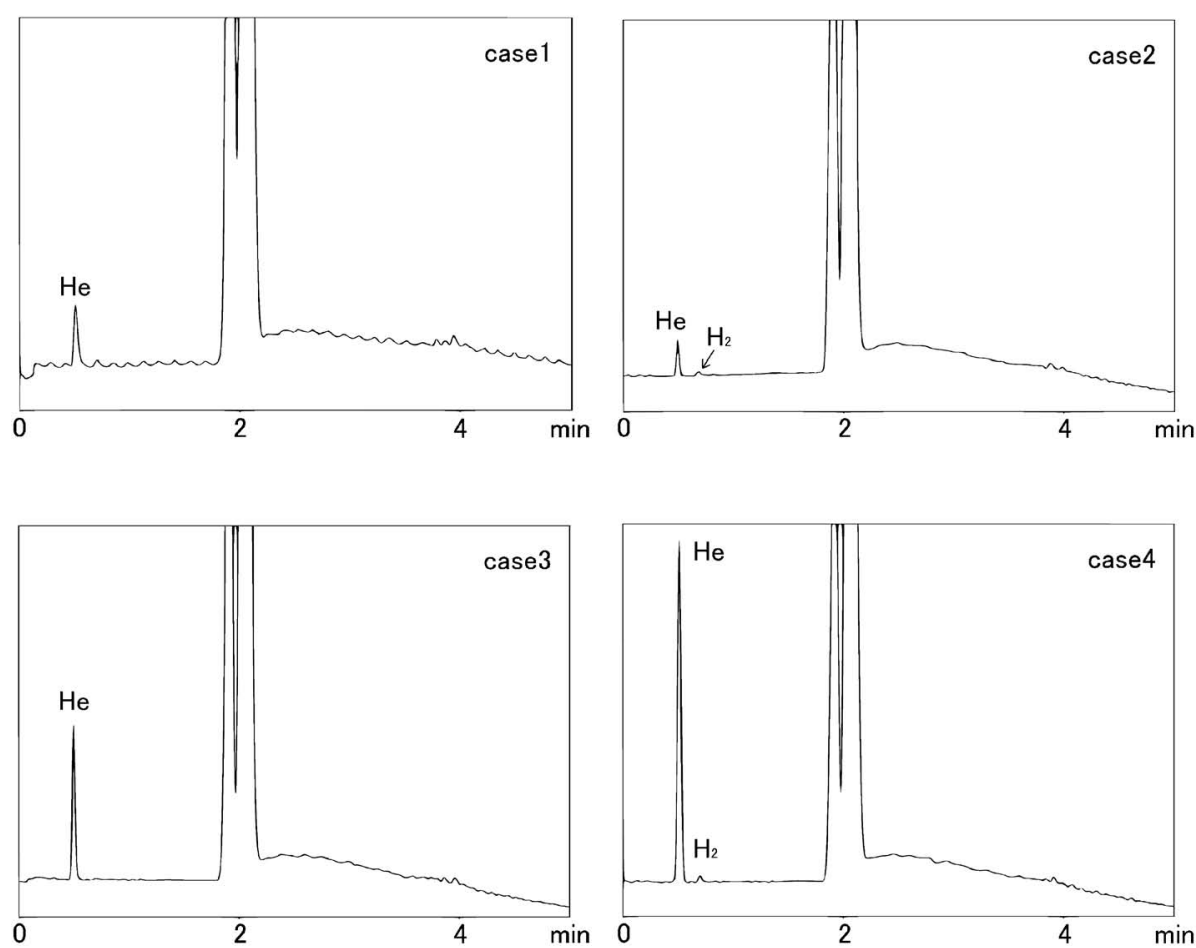

Fig. 3 Gas chromatograms obtained from the blood samples of four cases. 
1, 2 よりも強い強度でヘリウムが検出された。この 理由として，血液の量が事例 1,2 より多く，その 分へッドスペースが狭いためへッドスペース内のへ リウムが高濃度になっていたことと，分析までの時 間が短かったことが考えられる。

〈事例 4〉自宅でヘリウムボンベ 2 個を用い自殺を 図っていたもので，死者の身体に法医学的所見は観 察されなかった. 死亡推定日から採血までの日数は 1 日で，採血当日に分析を行った。血液は 2 本持ち 达まれ，液量はそれぞれ約 $3.5 \mathrm{ml}$ と約 $4 \mathrm{ml}$ であっ た．分析までに試料を TCDの熱で加熱し（時間は 測定していない)，バイアルが減圧であることを考 慮してバイアルに空気 $0.5 \mathrm{ml}$ を入れた後へッドス ペースガス $0.5 \mathrm{ml}$ を採取した. 血液量 $3.5 \mathrm{ml}$ の試料 を分析した結果を Fig. 3 case 4 に示す. 本事例では これまでの中で最も強い強度でへリウムのピークが 検出され，また，血液量で比較した場合には液量約 $4 \mathrm{ml}$ の方が液量約 $3.5 \mathrm{ml}$ の1.4倍のピーク面積が得 られた。従って, 血液量が多く, ヘッドスペースが 狭い方が，ヘリウムの濃度が高くなり, 明瞭な検出 が可能であると考えられる.

\section{3. 前処理法の検討}

\section{3-1 加温の効果}

ヘリウム水溶液を入れたバイアルを，室温または $60^{\circ} \mathrm{C}$ 温浴内で 15,30 抢よび 60 分間静置し，そのへ ッドスペースガス $0.5 \mathrm{ml}$ を GCで分析した（ $n=$ 3). その結果, Fig. 4 に示すように, 室温, $60^{\circ} \mathrm{C}$ い ずれの温度でも静置時間によらずそれぞれほぼ一定 值を示したことから，どちらも15分で既に平衡に達

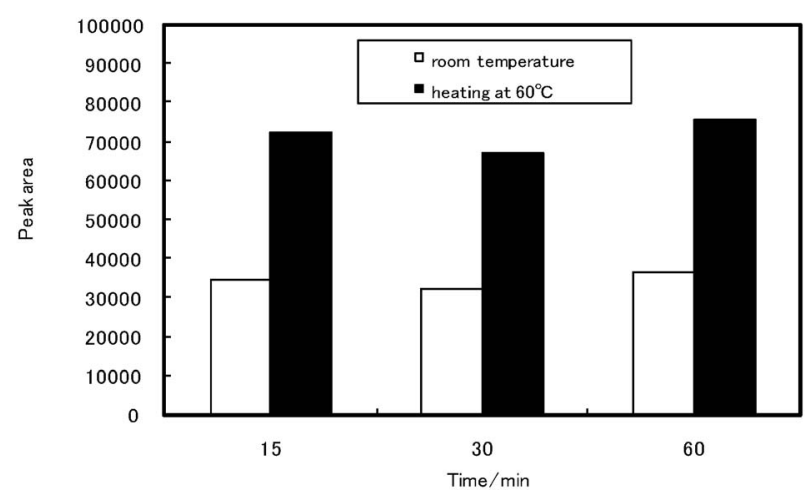

Fig. 4 Effect of heating
していると考えられた。 また, 加温を行った場合は 室温で静置した場合の約 2 倍のピーク面積が得ら れ, 加温がへリウムの分析に効果があることが明ら かになった．以上のことから，血中へリウムの分析 は, $60^{\circ} \mathrm{C} て ゙ 15$ 分以上加温することが効果的と考えら れた.

\section{3-2 注入量の検討}

$\mathrm{GC}$ の注入量 $0.5 \mathrm{ml}$ と $1.0 \mathrm{ml}$ のときのピーク面積 および強度を比較したところ, 注入量を $1.0 \mathrm{ml}$ とす ることでピーク面積は約 1.2 倍, ピーク強度は約 1.3 倍となった. 今回注入量を多くしてもピーク形状に 影響はなかった。ヘリウムの検出においては可能な 限り注入量を増やすことが有効であると考えられ る.

\section{3-3 注入法の検討}

スプリット注入法では，スプリット比を下げる （1：5）とピークがブロードになった. スプリット レス注入法ではへリウムピークとして検出すること ができなかった。な㧍，スプリットレス注入法では サンプリングタイムを 0.5 分とすることでピークを 検出可能となったが，そのピークはブロードであっ た. サンプリングタイム 0.1 分ではピークはシャー プで水素との分離も可能であったが，得られるピー ク面積はスプリット注入法（スプリット比 1：10） の場合の 9 割程度であった. スプリットレス高圧注 入法を試みたところ, ピーク面積はスプリット法 （スプリット比 1：10）の場合の約1.6倍と良好であ った. しかし分析が始まると同時にベースラインが 上がってしまい，また，ヘリウムの保持時間が約 0.3分と早くなりベースラインが安定していないう ちに検出されてしまうため, ヘリウムの検出には適 していないと考えられた。

\section{4. 最適な分析方法}

以上の検討結果より，血中へリウムの分析には， あらかじめ密栓して容量 $60 \mathrm{ml}$ のプラスチックシリ ンジで内部を減圧にした $4 \mathrm{ml}$ 用のオートサンプ ラー用バイアルを用い, 検視などで採血した注射器 の針をバイアルのセプタムに直接刺して血液を入 れ， $60^{\circ} \mathrm{C}$ で 15 分間加熱し，ヘッドスペースガス 1 $\mathrm{ml}$ を採取しスプリット注入法（スプリット比 1 : 10）により分析する方法が最適と考えられた. 


\section{結 論}

ヘリウム吸引の証明として，血液からのヘリウム の検出を試みた. $4 \mathrm{ml}$ 用のオートサンプラー用バ イアルをあらかじめ密栓後, 内部を減圧とし, 検視 で採取した血液を入れて分析に供することで, 血液 中のヘリウムの検出が可能であった.

\section{文献}

1）化学大辞典 8 縮刷版. pp. 390-391, 共立出 版, 東京 (1964).

2）公文啓二：ヘリウム酸素吸入療法. 呼吸, 16, 1274-1279 (1997).

3）石澤不二雄, 乗峯絵理, 本田克也 : インター ネットに影響されるガス中毒の変遷. 中毒研 究, 24, 3-8 (2011).

4) Ogden, R. D. and Wooten, R. H.: Asphyxial Suicide with Helium and a Plastic Bag. Am. J. Forensic Med. Pathol., 23, 234-237 (2002).

5) Gallagher, K. E., Smith, D. M. and Mellen, P. F.: Suicidal Asphyxiation by Using Pure Helium Gas: Case Report, Review, and Discussion of the Influence of the Internet. Am. J. Forensic Med. Pathol., 24, 361-363 (2003).

6) Saint-Martin, P., Prat, S., Bouyssy, M. and
O’Byrne, P.: Plastic bag asphyxia -A case report. Journal of Forensic and Legal Medicine, 16, 40-43 (2009).

7) Yoshitome, K., Ishikawa, T., Inagaki, S., Yamamoto, Y., Miyaishi, S. and Ishizu, H.: A Case of Suffocation by an Advertising Balloon Filled with Pure Helium Gas. Acta Med. Okaya$m a, 56,53-55$ (2002).

8) Auwaerter, V., Perdekamp, M. G., Kempf, J., Schmidt, U., Weinmann, W. and Pollak, S.: Toxicological analysis after asphyxial suicide with helium and a plastic bag. Forensic Science International, 170, 139-141 (2007).

9) Kelly, A., Shahreza, S., Danielson, T., Guale, F. and Mozayani, A.: Helium Detection in Postmortem Specimens. American Academy of Forensic Sciences 2011, 447-448 (2011).

10）浅野水辺, 森近舞, 中川加奈子, 近藤武史, 久世安澄,リチャードH. カシンスキー, 櫻田 誠，上野易弘：ヘリウム吸入による自殺の一剖 検例. 日法医誌， 65, 150 (2011).

11）横谷馨倫, 戸谷誠之：消化機能評価における 呼気中水素ガス濃度の意義. 学苑 ·生活科学紀 要, 806, 15-22 (2007). 